\title{
Conserving the endemic birds on the Comoro Islands, II: population fluctuations on Ngazidja
}

\author{
JAN STEVENS, MARC HERREMANS and MICHEL LOUETTE
}

\begin{abstract}
Summary
Land bird abundances on Ngazidja, Comoro Islands, obtained by point counts in September 1985 and November-December 1989 are compared. The overall abundance of most species did not differ significantly. Most differences can be interpreted as normal within-year fluctuations. Some important changes are identified and attributed to shortterm vegetation changes: increase of Columba polleni, Coracopsis vasa, Zoonavena grandidieri, Coracina cinerea in Nioumbadjou after abandonment of forest exploitation; decrease of Coracina cinerea at M'Lima Mani North after replacement of the natural shrub layer by bananas. Genuine long-term population changes occur in Coracopsis nigra (increase) and Corvus albus (decrease).
\end{abstract}

Il s'agit d'une comparaison entre les abondances d'oiseaux terrestres, relevées sur Ngazidja, îles Comores, au cours de comptages par points effectués en septembre 1985 et novembre-décembre 1989. L'abondance générale de la plupart des espèces ne diffère pas de façon significative. La plupart des différences peuvent être interprétées comme des fluctuations annuelles normales. Des changements importants sont identifiés et attribués à des changements de végétation à court terme: augmentation de Columba polleni, Coracopsis vasa, Zoonavena grandidieri, Coracina cinerea dans Nioumbadjou après l'abandon de l'exploitation de la forêt; diminution de Coracina cinerea au Mont Lima Mani Nord après le remplacement de la couche d'arbustes naturelle par des bananiers. De véritables changements de population à long terme sont observés chez Coracopsis nigra (augmentation) et chez Corvus albus (diminution).

\section{Introduction}

As small oceanic islands, the Comoros are an excellent subject for the investigation of aspects of island biogeography, speciation and insularization. Furthermore the large proportion of bird taxa endemic to the Comoros makes them important for bird and nature conservation. Ngazidja is the largest island and supports the largest area of evergreen forest. The protection of most endemic species is closely linked to the conservation of the forest on the slopes of the Karthala volcano. Ngazidja is a good model to investigate the effect of forest exploitation and clearance on bird species and communities. On most other islands in the Indian Ocean forest degradation is further advanced and a larger number of endemics have already become extinct (Diamond 1987).

This study had three primary aims: (1) to establish the population size of the endemics; (2) to determine their habitat preference; and (3) to assess the extent to which they are threatened by human activities.

To answer the above questions we censused birds in September-October 1985 
by means of point-counts on transects along the slopes of Mount Karthala. With these census data we described distribution and abundance of each species in view of actions to be taken for their conservation (Louette et al. 1988). During a new mission in November-December 1989 eight of the transects taken in 1985 were repeated in addition to a series of new ones. In this (second) paper, these data, which give an idea of differences in abundance between 1985 and 1989 , are discussed in view of present knowledge of bird population fluctuations on tropical islands.

In Part I (Louette and Stevens, previous paper in this issue) we reviewed the status of the Comoro endemic birds from different points of view (avifaunal composition of the islands, colonization history, altitudinal distribution and density, preliminary data on habitat preference) in relation to their chances of survival. A third paper (in preparation) will concentrate on ecological aspects of endemic bird conservation on the Comoro Islands.

\section{Material and methods}

A modification of the classic point-transect counts was used to measure bird abundances (Hustings et al. 1985). At each station two observers each performed 1o counts of 15 minutes each from points at least $200 \mathrm{~m}$ apart. The counting points were distributed along a transect spaced out well enough to minimalize chances of double counting. Counts were performed either during the first three hours after sunrise or during the last two hours before sunset. During November 1989 the same transects as in September-October 1985 were revisited whenever possible. J.S. counted in 1985 as well as in 1989; in 1985 he was accompanied by L. Bijnens, in 1989 by M.H., M.L. or D. Vangeluwe. For a detailed description of the counting stations, see Louette et al. (1988).

Numbers counted at the 20 points of a station are converted into an abundance for the whole station, i.e. the total number of individuals per counting station.

Between both years numbers are compared per species and per station $(20 \times 15$ min) by means of a test of independence using the G-test or for small samples the Fisher exact probability test (Sokal and Rohlf 1969) on the number of counts the species was recorded in, and/or on the total number of individuals per count. Alternatively a Wilcoxon matched-pairs signed-ranks test was used on the data of all points. Two tests were used and compared because it is difficult to test this type of contingency data reliably. Data are also compared with qualitative data on distribution and abundance given in Benson (1960) and Louette (1988).

For each counting point the vegetation was described. These data (from 1985) can be found in Louette et al. (1988). In 1989 no measurable differences in vegetation were found although at some stations qualitative differences were obvious. Weather conditions were also recorded.

\section{Results and discussion}

Table 1 presents the bird abundances recorded and the significance of occasional differences. Only 34 of the 272 abundances differ significantly in one or another test $(12.5 \%)$. Eleven abundances $(4.04 \%)$ differ for the G-test of independence or 


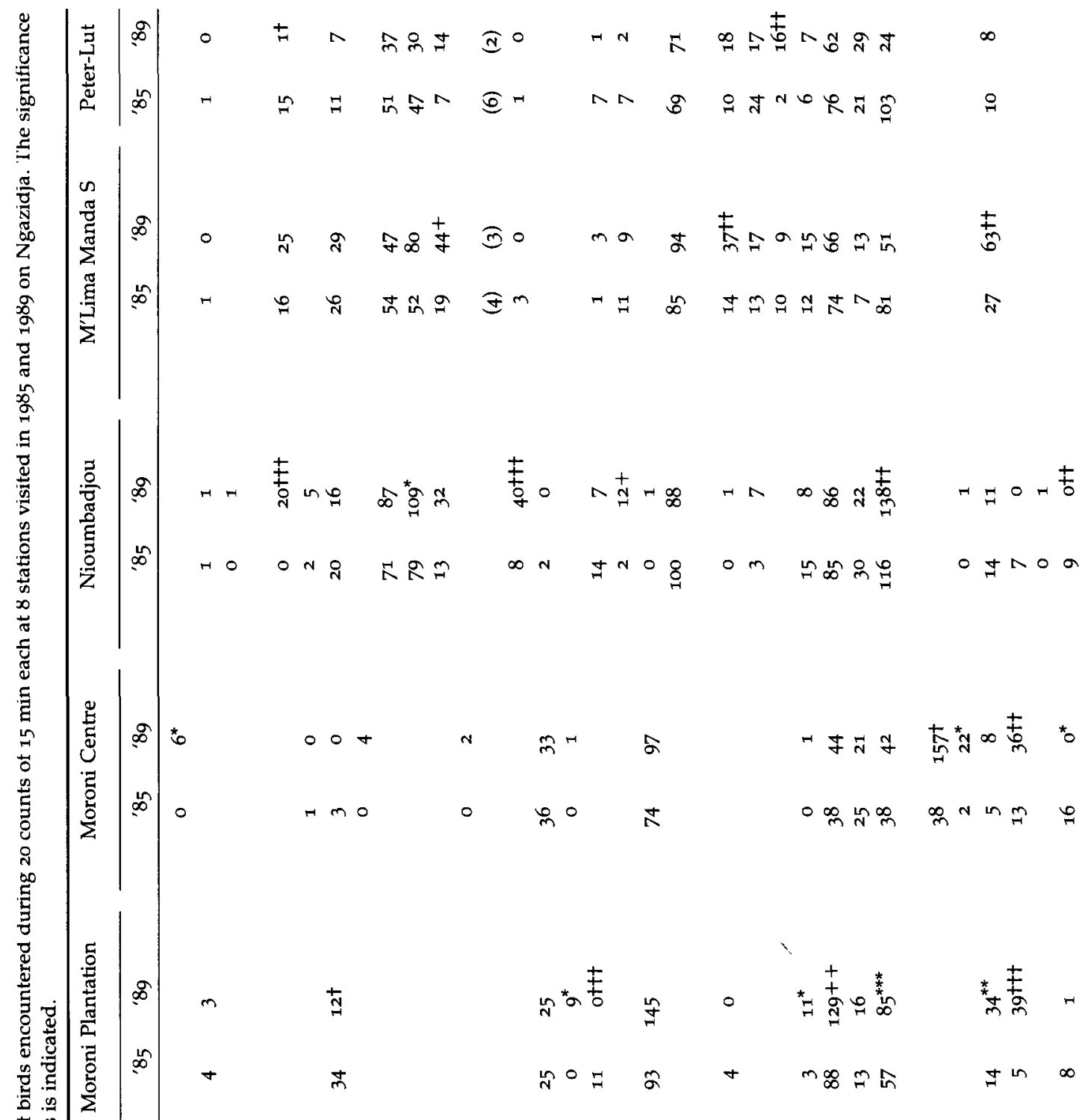




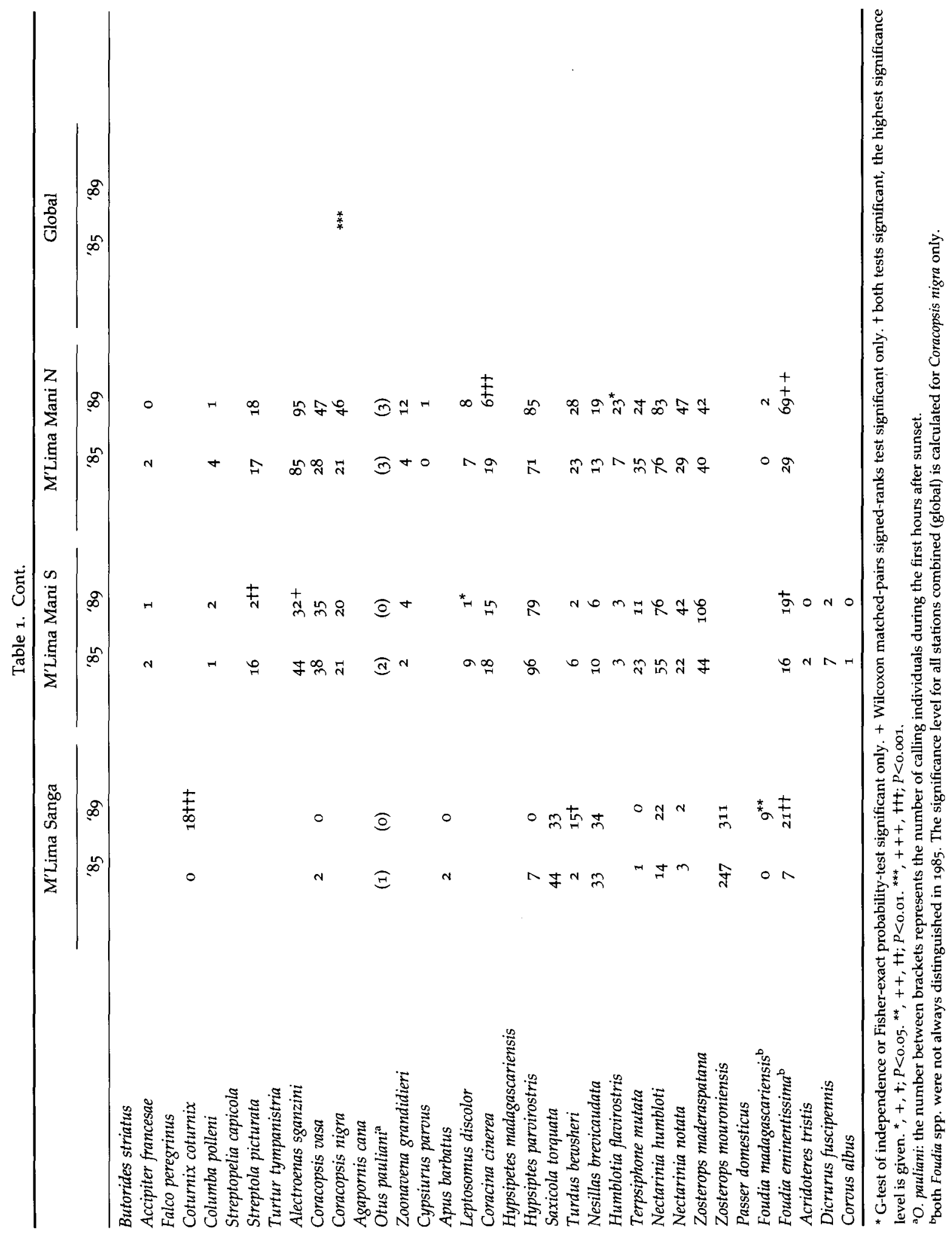


Fisher exact probability test only, five $(1.83 \%)$ for the Wilcoxon matched-pairs signed-ranks test only, while the remaining $18(6.61 \%)$ differ for both tests.

\section{Species with changed abundance}

The Striated Heron Butorides striatus was recorded in 1989 at Moroni more frequently than in 1985 . Nevertheless the species was also seen there outside the counts in 1985 and in August and September 1983. Benson (1960) states "... found in all coastal areas, in small numbers, usually solitary". We had the same overall impression. The breeding season is probably about October. Benson found nests with two-week old pulli on Maore on 24 October, and Louette (1988) indicated building activities at Iconi on 23 October. The higher abundance in 1989 is probably due to recently fledged juveniles.

In 1989 Frances's Sparrowhawk Accipiter francesae was less frequently recorded at five stations, and in similar numbers at another. The overall trend is a decline, but statistically this is not significant due to the extremely small numbers of individuals and the restricted number of stations. Benson (1960) states that in September the species is not in breeding condition. In November 1989 we found a pair on an empty nest. Possibly the species is less in view in the nest-building period in November than outside the breeding season in September.

The Common Quail Coturnix coturnix was much more abundant at M'Lima Sanga in 1989 than in 1985 . Benson (1960) found it locally plentiful in short grassland and cultivation. Our observations agree with this habitat description. The difference between 1985 and 1989 is probably due to the very irregular singing activity of this species. But since this species is also known to migrate between Africa and Madagascar (Milon et al. 1973), differences in abundance could be due to the presence or absence of migrants.

We found the Comoro Pigeon Columba polleni relatively abundant at Nioumbadjou in 1989, a station where the species had never been recorded before. At Peter-Lut the species was less abundant than in 1985. At the other stations no significant differences were found. Benson (1960) stated that the species does not occur below $700 \mathrm{~m}$. In 1985 we found it already in the zone between 500 and $750 \mathrm{~m}$. This may be due to the abandonment of active forest exploitation in Nioumbadjou.

As noted by Benson (1960) the Madagascar Turtledove Streptopelia picturata is common throughout the archipelago. Comparing counts of 1985 and 1989 shows an overall decline. At two stations (Moroni Plantage and M'Lima Mani South) the difference is significant. Because this species is discovered mainly acoustically, we also tested whether calling was related to weather conditions. At Moroni Plantage and M'Lima Mani South no relation was found; at Peter-Lut, however, we found fewer doves singing during windy counts $(G=7.7002$, $P<0.01)$. The breeding season falls in October-November according to Benson (1960). It is possible that in 1985 the species was still in the pre-breeding period with a higher level of song activity than in the breeding period of November 1989.

According to Benson (1960) the Comoro Blue Pigeon Alectroenas sganzini was very common in the canopy of evergreen forest in 1958. This impression is 
confirmed by our counts. No significant difference was found between both years except for one station.

The Greater Vasa Parrot Coracopsis vasa is an abundant species according to Benson (1960) and Louette (1988). Only at one station (Nioumbadjou) were numbers higher in 1989. Perhaps near Nioumbadjou the population increased after abandonment of forest exploitation activities in 1986. At the other stations no overall trend was apparent. We assume that the overall population remained similar in size.

The Lesser Vassa Parrot Coracopsis nigra shows a significant overall increase in abundance between 1985 and 1989 . According to Benson (1960) this species is associated with evergreen forest but is less common than the Greater Vasa Parrot. Louette (1988) found it relatively common in the Karthala forest down to $400-500 \mathrm{~m}$, while this study showed the species to be less frequent and more restricted to higher altitudes in 1981 and 1983 than in 1989 . In 1989 this parrot was also abundant in the gardens around Mvouni.

The Karthala (Grand Comoro) Scops Owl Otus pauliani was, of course, not recorded during the diurnal point-counts. We recorded the number of territorial birds during a few hours after sunset. The total number counted is given (between brackets) in Table 1 . In four of five stations numbers were lower in 1989. It is very difficult to know if this reflects a real population decline. In each case the species reacted strongly to imitation of territorial calls in November 1989. In some cases the lower number in 1989 was almost certainly due to windy and rainy weather conditions, e.g. at M'Lima Manda South, Peter-Lut and M'Lima Sanga after sunset. The status of this species is treated in detail elsewhere (Herremans et al. 1991).

The Madagascar Spine-tailed Swift Zoonavena grandidieri showed a significant increase at Nioumbadjou. At the other stations abundances were low and similar in both years. In 1989 the situation seemed still to be comparable with the impression Benson (1960) had in 1958: "At Nioumbadjou it was always to be seen, hunting in clearings or along narrow roads in the evergreen forest". In 1981 Louette observed about 10 individuals during a visit to Nioumbadjou. It seems that with the abandonment of the activities of the sawmill, the population had recovered to the levels it enjoyed before forest exploitation began.

The African Black Swift Apus barbatus was more abundant in Moroni Plantation in 1989. No breeding data are available for the Comoros although Benson (1960) suggested that egg-laying could be in late September. In that case the increase could be due to juveniles accompanying adults in November 1989. On the other hand the result could be a chance event caused by the mere incidental foraging of a group above the counting station in 1989.

The Cuckoo-roller Leptosomus discolor was recorded less frequently in 1989 than in 1985. At two stations the decrease was significant. The singing performance of this species during the course of the day is very irregular (see also Herremans 1988) making it difficult to distinguish population fluctuations from differences in singing performance. At M'Lima Mani North in 1989 we observed a pair with one juvenile. A few weeks later we found nestlings. This species may call less frequently when feeding young, resulting in the reduced number of records in 1989 .

In 1989 the Ashy Cuckoo-shrike Coracina cinerea was less abundant at all 
stations except Nioumbadjou. At M'Lima Mani North the decline was significant. The increase in Nioumbadjou was very pronounced $(\times 6)$ and statistically significant. This species seems to have a clear preference for a well-developed shrub-layer. At M'Lima Mani North this stratum has been destroyed by planting bananas under the forest. At Nioumbadjou our counting-points were spaced out along the corridors down which the forest was still being exploited during 1985 . In 1989 shrubs had overgrown these corridors. We have the impression that local abundances fluctuate depending on the availability and quality of the shrub-layer.

The Comoro Thrush Turdus bewsheri was more abundant in 1989. At two stations the difference was significant. Benson (1960) found this species especially abundant at Nioumbadjou, an observation not supported by our data. The abundance of this species was low at Nioumbadjou in comparison to other forest stations during 1985 and 1989. Since Benson (1960) found nests in October and Louette (1988) in September-October, the overall increase in numbers between 1985 and 1989 may be due to recently fledged juveniles. However, none of the nine birds mist-netted in 1983 and 1989 was juvenile, suggesting that reproduction is probably not massive in this species.

Humblot's Flycatcher Humblotia flavirostris was more abundant in 1989 than in 1985 at Peter-Lut and at M'Lima Mani North. At the other stations the abundance was similar. This was probably due to a good breeding season.

The Madagascar Paradise Flycatcher Terpsiphone mutata showed no clear pattern except at Moroni Plantation. The increase at this station was due to the (fortuitous) observation during the counts of a family of fledglings in the neighbourhood of a nest. In 1983 nine adults, of which five were in breeding condition, and in 1989 five birds, all in breeding condition, were caught.

Humblot's Sunbird Nectarinia humbloti was more numerous at Moroni Plantation in 1989. Elsewhere this species showed no clear trend between both years. Our impression of density agrees with those of Benson (1960) and Louette (1988), namely that this is a very abundant species.

In 1989 the Madagascar White-eye Zosterops maderaspatana was more abundant at Moroni Plantation and at Nioumbadjou, but at two other stations we found a decline. However, at both these stations the weather was rainy and since the species is mainly recorded acoustically or when foraging in groups, the decline in the recordings may be related to unfavourable weather. The large difference between years in Peter-Lut is an artefact of counting efficiency: a significant difference between the two observers indicates that one of them consistently overlooked the species. Taking into account these points it is most likely that there had been an overall population increase. This was also probably due to fledged juveniles since Benson (1960) assumed that the breeding season begins in September.

The abundance of the House Sparrow Passer domesticus increased significantly in Moroni between 1985 and 1989 . Yet Benson (1960) found this species very common, associated with stone buildings. Since the number of stone buildings has increased markedly in Moroni the established population increase probably reflects a long-term upward trend.

In 1985 we did not distinguish between the two fody species, thus making comparison between years very difficult. Nevertheless, in 1989 the Madagascar 
Fody Foudia madagascariensis was more abundant at Moroni Centre than F. madagascariensis and the Comoro Fody F. eminentissima combined in 1985. Overall, $F$. eminentissima was more abundant in 1989 . The difference was significant at three stations. Since males of both species were in breeding plumage in 1989 they probably also were more territorially active, and thus more conspicuous than in September-October 1985 when $F$. eminentissima was still frequently recorded as a member of mixed-species groups. During September-October males of F. madagascariensis were still in eclipse plumage.

The Common Myna Acridotheres tristis increased significantly in number between September 1985 and November 1989 at Moroni Centre and at Moroni Plantation. The species disappeared from Nioumbadjou, probably as the result of dense vegetation that had overgrown the open forest plots previously under exploitation. The species prefers more open country and clearings in the forest. The marked increase at Moroni probably reflects a long-term population increase parallel with the increase of cattle on the island.

The population of the Pied Crow Corous albus showed a clearly decreasing trend; at two stations the decrease was significant. Benson (1960) indicated the crow as "common throughout the archipelago". Louette (1988) says "à basse altitude c'est un ubiquiste .. .". These statements were no longer correct in 1989 . The crow had become very rare. The only concentration observed was at the rubbish tip midway between Moroni and Hahaya where about 25 birds were present on 25 November 1989.

\section{Species with similar abundance}

For reasons of completeness we note that neither in 1985 nor in 1989 was the Black Kite Milvus migrans recorded. Benson (1960) indicated the species as "a familiar sight in the neighbourhood of human habitation throughout the archipelago, usually solitary". Louette (1988) reviewed observations during recent years. Our data confirm his conclusion that the species has disappeared from Ngazidja.

The Madagascar Harrier Circus maillardi was not recorded in the counts. This is due to the position of most stations within the forest under the canopy.

The Peregrine Falcon Falco peregrinus was noticed once in 1989 but not in 1985. We agree with Benson (1960) and Louette (1988) that the species is present but in very low numbers.

The Ring-necked Dove Streptopelia capicola, the Tambourine Dove Turtur tympanistria and the Grey-headed Lovebird Agapornis cana were only very sporadic in our counts because they avoid forest.

The African Palm Swift Cypsiurus parvus was observed frequently at Moroni.

The Madagascar Bulbul Hypsipetes madagascariensis and Comoro Bulbul $H$. parvirostris both were very abundant throughout their altitudinal range. No difference in abundance was established.

The Blue Vanga Cyanolanius madagascarinus was not recorded in 1985 nor in 1989, and the holotype of Louette and Herremans (1982) remains the only recent record on Ngazidja. 
The Stonechat Saxicola torquata was only present in the counts at M'Lima Sanga with comparable abundances in both years.

The Grand Comoro Brush-warbler Nesillas brevicaudata and the Long-billed Green Sunbird Nectarinia notata showed no significant differences in abundance between both years. Our counts agree with the impressions of Benson (1960) and Louette (1988).

The Karthala White-eye Zosterops mouroniensis was only encountered at M'Lima Sanga, and its abundance was comparably high in 1985 and 1989.

The Grand Comoro Drongo Dicrurus fuscipennis was only exceptionally encountered in both years. On the basis of our counts the species is too sparsely distributed to allow speculation on its population dynamics. Outside the counts of 1989, the species was found singing and displaying in coconut plantations near Singani, on the south-west coast. Three pairs were observed at this new locality.

\section{Conclusions}

About $12 \%$ of the measured abundances were different between September 1985 and November 1989 and some were highly significant. Apart from artefacts resulting from the weather (e.g. Streptopelia picturata and Otus pauliani) or irregular song pattern (Leptosomus discolor and perhaps Coturnix coturnix), two categories of difference can be distinguished.

Some differences in abundance are due to within-year fluctuations. For some species September and November represent different parts of the breeding season. We suppose that Foudia eminentissima was more conspicuous in the prebreeding period of November 1989 than in September when they were mainly found in mixed-species groups. Accipiter francesae and Streptopelia picturata were more vocal in 1985 in their pre-breeding period than later in the breeding season during 1989. Butorides striatus, Apus barbatus, Turdus bewsheri, Humblotia flavirostris, Terpsiphone mutata and Zosterops maderaspatana were more numerous after the breeding season in November 1989. This increase can be due to recently fledged young. However, we caught almost no recently fledged juveniles in our mist-netted samples of Turdus bewsheri, Humblotia flavirostris, Terpsiphone mutata and Zosterops maderaspatana. Although the size of the netted samples was quite restricted, this observation seems to be relevant. However, because no data are yet available on moulting cycles and speed in these species, it is possible that juveniles moult very early and rapidly after leaving the nest, so that a short time after fledging they become indistinguishable from adults (see, for example, a similar case in the bulbuls; Louette and Herremans 1985). In contrast to the results of netting, we clearly observed adults feeding juveniles in small groups (possibly families) of Humblotia flavirostris and Terpsiphone mutata in November 1989. Fogden (1972) noticed a long period of parental care in forest birds on Sarawak, including feeding which might last for as long as six to seven months in insectivorous species that use skilful foraging techniques. This might also hold for our two species of flycatchers.

Differences in abundance may also be the result of between-year fluctuations. Since data on avian population dynamics in tropical forests in Brosset (1989), 
Fogden (1972), Frith (1976) and Prŷs-Jones and Diamond (1984) indicate only small breeding success and small population fluctuations, our observed differences in abundance probably reflect the cumulative result of small changes in the five years between our two counts. On the other hand Gibbs and Grant (in Boag 1986) noticed a ten-fold increase of Darwin's Medium Ground Finch Geospiza fortis on Daphne Major Island, Galápagos, in a single breeding season. The endemic Seychelles Warbler Acrocephalus sechellensis also showed a spectacular increase on Cousin Island after management of its habitat and the behaviour of this species after translocation onto Aride (Komdeur et al. 1991) proved that a large population increase can occur if environmental circumstances suddenly improve. Apparently these species can switch from a $K$-reproductive strategy representing a high population level with a low reproductive output, to an $r$ strategy with maximal reproduction (MacArthur and Wilson 1967).

Thus it seems that large population changes between years can be caused by changes in vegetation or other habitat parameters. When such changes occur in a restricted part of the island they result in local changes in bird numbers. The increased abundance of Columba polleni, Coracopsis vasa, Zoonavena grandidieri and Coracina cinerea at Nioumbadjou after the abandonment of the exploitation of the forest are interpretable in this way. The decrease of Coracina cinerea at M'Lima Mani North is attributable to the disappearance of the shrub-layer there. Perhaps the increasing cultivation of bananas in the undergrowth of the forest can explain the increase of Foudia eminentissima, since this species is frequently seen feeding on banana flowers. The populations of Passer domesticus and Acridotheres tristis seem to follow the growing human population and the increasing number of cattle, respectively.

Genuine long-term population changes can be the result of climatic changes, changed inter-species competition, genetic drift to more or less successful genotypes or merely chance. Which of these can best explain the overall increase of Coracopsis nigra, the obvious decrease of Corvus albus and the disappearance of Milvus migrans is not clear. We must conclude, however, that the lack of knowledge about breeding biology, population dynamics and general ecology of the populations on Ngazidja prevents us from giving interpretations for most differences in abundance we found between 1985 and 1989 .

With respect to the conservation of the endemic species the comparison of the abundances between both years does not indicate serious threats within a short time-span. Only Dicrurus fuscipennis is too rare to speculate about its population dynamics and probably this species is most in danger. However, the threat to endemic birds must also be considered in the light of the human impact on their habitat. If human activities interfere with essential parameters of the habitat, dramatic population changes can occur as is known from the bird history of other islands, e.g. the Mascarenes (Diamond 1987). The habitat choice and ecological requisites are not treated in this text, but will be investigated elsewhere.

\section{References}

Benson, C. W. (1960) The birds of the Comoro Islands: results of the British Ornithologists' Union Centenary Expedition 1958. Ibis 103b: 5-106. 
Boag, P. T. (1986) The genetics of island birds. Acta XIX Congr. Internatn. Orn. 1986: 1550-1563.

Brosset, A. (1989) Population dynamics of birds in a northeastern Gabon forest. Ostrich (suppl.) 14: 1-6.

Diamond, J. M. (1985) Population processes in island birds: immigration, extinction and fluctuations. Pp. 17-21 in P. J. Moors, ed. Conservation of island birds. Cambridge, U.K.: International Council for Bird Preservation (Techn. Publ. 3).

Diamond, A. W., ed. (1987) Studies of Mascarene Island birds. Cambridge, U.K.: Cambridge University Press.

Fogden, M. P. L. (1972) The seasonality and population dynamics of equatorial forest birds in Sarawak. Ibis 114: 307-343.

Frith, C. B. (1976) A twelve-month field study of the Aldabran Fody Foudia eminentissima aldabrana. Ibis 118: 155-178.

Herremans, M. (1988) Inter-island variation in bird vocalizations on the Comoros. Proc. 6th Pan-Afr. Orn. Congr.: 281-295.

Herremans, M., Louette, M. and Stevens, J. (1991) Conservation status and vocal and morphological description of the Grand Comoro Scops Owl Otus pauliani Benson 1960. Bird Conserv. Internatn. 1: 123-133.

Hustings, M. F. H., Kwak, R. G. M., Opdam, P. G. M. and Reynen, M. J. S. M. (1985) Vogelinventarisatie, achtergronden, richtlijnen en verslaggeving. Wageningen: PUDOC.

Komdeur, J., Bullock, I. D. and Rands, M. R. W. (1991) Conserving the Seychelles Warbler Acrocephalus sechellensis by translation: a transfer from Cousin Island to Aride Island. Bird Conserv. Internatn. 1: 177-185.

Louette, M. (1988) Les oiseaux des Comores. Ann. Mus. R. Afr. Cent., Zool. 255: 1-192.

Louette, M. and Herremans, M. (1982) The Blue Vanga Cyanolanius madagascarinus on Grand Comoro. Bull. Brit. Orn. Club 102: 132-135.

Louette, M. and Herremans, M. (1985) Taxonomy and evolution in the Bulbuls (Hypsipetes) on the Comoro Islands. Proc. Internatn. Symp. African Vertebr., Bonn 1985: $407-423$.

Louette, M., Stevens, J., Bijnens, L. and Janssens, L. (1988) A survey of the endemic avifauna of the Comoro Islands. Cambridge, U.K.: International Council for Bird Preservation (Study Report 25).

MacArthur, R. H. and Wilson, E. O. (1967) The theory of island biogeography. Princeton: Princeton University Press.

Milon, P., Petter, J. J. and Randrianasolo G. (1973) Faune de Madagascar: XXXV Oiseaux. Paris: CNRS.

Prŷs-Jones, R. P. and Diamond, A. W. (1984) Ecology of the land birds on the granitic and coraline islands of the Seychelles, with particular reference to Cousin Island and Aldabra Atoll. Pp. 529-558 in D. R. Stoddart, ed. Biogeography and ecology of the Seychelles Islands. The Hague: Dr W. Junk.

Sokal, R. R. and Rohlf, F. J. (1969) Biometry: the principles and practice of statistics in biological research. San Francisco: W. H. Freeman.

\section{JAN STEVENS}

Provinciaal Natuurcentrum, Zuivelmarkt 33, B-3500 Hasselt, Belgium

\section{MARC HERREMANS}

Department of Wildlife and National Parks (Ornithology Section), P.O. Box 131, Gaborone, Botswana

MICHEL LOUETTE

Koninklijk Museum voor Midden-Afrika, B-3080 Tervuren, Belgium 